\title{
Experimental study on antitumor effect of arsenic trioxide in combination with cisplatin or doxorubicin on hepatocellular carcinoma
}

\author{
Wei Wang ${ }^{1}$, Shu-Kui Qin ${ }^{1}$, Bao-An Chen ${ }^{2}$ and Hui-Ying Chen ${ }^{1}$
}

${ }^{1}$ Chinese PLA Cancer Center, Chinese PLA 81 Hospital, Nanjing 210002, Jiangshu Province, China

${ }^{2}$ Affliliated Zhongda Hospital of Southeast University Medical College, Nanjing 210087, Jiangsu Province, China

Supported by the Youth Science Grant of Jiangshu Province, No. BQ98048.

Correspondence to: Prof. Shu-Kui Qin, Chinese PLA Cancer Center, Chinese PLA 81 Hospital, Nanjing 210002, Jiangshu Province, China. Qinsk@jlonline.com

Telephone: +86-25-6648090 Ext.529

Received 2001-02-06 Accepted 2001-06-10

Subject headings liver neoplasms; carcinoma, hepatocellular; tumor cells, cultured/drug effects; arsenicals/ pharmacology; cisplatin/pharmacology; doxorubicin/ pharmacology

Wang W, Qin SK, Chen BA, Chen HY. Experimental study on antitumor effect of arsenic trioxide in combination with cisplatin or doxorubicin on hepatocellular carcinoma. World J Gastroenterol, 2001;7(5):702-705

\section{INTRODUCTION}

The main component of a traditional Chinese drug "Pishuang", arsenic trioxide $\left(\mathrm{As}_{2} \mathrm{O}_{3}\right)$, has obviously selective anti-tumor effect on human hepatocellular carcinoma (HCC) in both in vitro and in vivo studies ${ }^{[1-5]}$. Due to limited effectiveness when any anti-carcinogen is used alone and obviously increased toxicity when the dose is raised, there is no exception for $\mathrm{As}_{2} \mathrm{O}_{3}$. Furthermore, combined chemotherapy contributes to improve therapeutic effectiveness, disperse toxicity and surmount drugresistance, in which the combination of traditional Chinese and modern medicine has more advantages and characteristics. As a result, we made an experimental study on anti-tumor effect of $\mathrm{As}_{2} \mathrm{O}_{3}$ in combination with cisplantin (PDD) or doxorubicin (ADM) on $\mathrm{HCC}$, to investigate the possibility of $\mathrm{As}_{2} \mathrm{O}_{3}$ in combination with PDD or ADM and nature of interaction between them, and to provide experimental basis for clinical application.

\section{MATERIALS AND METHODS \\ Materials}

Drugs and reagents $\mathrm{As}_{2} \mathrm{O}_{3}$ for injection ( $5 \mathrm{mg}$ per am poul, Lot No. 998068, provided by Professor Ma Jun of Harbin Hamaeotoloy and Oncolony Institute), PDD for injection (20 mg per vial, Lot No. 990618, Shandong Qilu Pharmaceutical Factory) or ADM hydrochloride for injection (10 mg per vial, Lot 990406, Shanxi Mlarmaceutical Co. LTD).

Cell lines Human hepatoma Bel-7402 cells were obtained from the Shanghai Cell Bank of Chinese Academy of Sciences and maintained in our laboratory. Bel-7402 cells were routinely cultured in RPMI1640 medium (Gibco) containing $100 \mathrm{~mL} \cdot \mathrm{L}^{-1}$ fetal calf (FCS) serum at $37^{\circ} \mathrm{C}$ in humidified incubator with $50 \mathrm{~mL} \cdot \mathrm{L}^{-1} \mathrm{CO}_{2} / 95 \mathrm{~mL} \cdot \mathrm{L}^{-1}$ air.

Animals Mice with hepatoma HepA were obtained from the Shanghai Institute of Materia Medica of Chinese Academy of Sciences and Kunming mice (famale and male weighing, $18 \mathrm{~g}$ $22 \mathrm{~g}$ ) from the Experimental Animal Center of Southerneast University Medical College.

\section{methods}

Measurement of anticancer activity in vitro The exponent growing Bel-7402 cells in culture flasks were harvested by $2.5 \mathrm{~g} \cdot \mathrm{L}^{-1}$ EDTA, suspended in RPMI1640 medium with $100 \mathrm{~mL} \cdot \mathrm{L}^{-1} \mathrm{FCS}$, adjusted to the concentration of $3 \times 10^{4}$ cells $\cdot \mathrm{L}^{-1}$, plated into 40 -well plates $(100 \mu \mathrm{L}$ cells $\cdot$ well- 1$)$ and incubated at $37^{\circ} \mathrm{C}$ in $50 \mathrm{~mL} \cdot \mathrm{L}^{-1} \mathrm{CO}_{2} / 95 \mathrm{~mL} \cdot \mathrm{L}^{-1}$ air until the cells were stuck with the plates. The cells were then exposed to $100 \mu \mathrm{L}$ of various concentrations of a drug alone or combination for $48 \mathrm{~h}$, and the controls to $100 \mu \mathrm{L}$ of RPMI1640 medium with no FCS. After that, the absorption was detected by adding $20 \mu \mathrm{L}$ tetrazolium (MTT) to each well, incubating for $4 \mathrm{~h}$, sucking out the media, adding $150 \mu \mathrm{L}$ dimethylsul foxide (DMSO) to dissolve the violet-crystal and measuring at $570 \mathrm{~nm}$. Double wells were used for each drug concentration. Experiments were triplicated. The inhibitory rate was calculated as follows:

$\operatorname{IR}(\%)=(1-$ mean absorption in experiments/mean absorption in controls $) \times 100 \%$

Measurement of anticancer activity in vivo The mice with hepatocarcinoma HepA were killed and their ascites Abstracted, adjusted to $2 \times 10^{7} \cdot \mathrm{mL}^{-1}$ and implanted by subcutaneous injection $200 \mu \mathrm{L}$ to each mouse. Sixty mice with implanted HepA tumor were randomly divided into control group (saline), and groups of $\mathrm{As}_{2} \mathrm{O}_{3}$ alone $\left(2 \mathrm{mg} \cdot \mathrm{kg}^{-1} \cdot \mathrm{d}^{-1}\right), \mathrm{PDD}$ alone $\left(1 \mathrm{mg} \cdot \mathrm{kg}^{-1} \cdot \mathrm{d}^{-1}\right), \mathrm{As}_{2} \mathrm{O}_{3}$ combin ed with PDD $\left(\mathrm{As}_{2} \mathrm{O}_{3} 2 \mathrm{mg} \cdot \mathrm{kg}^{-1} \cdot \mathrm{d}^{-1}+\mathrm{PDD} 1 \mathrm{mg} \cdot \mathrm{kg}^{-1} \cdot \mathrm{d}^{-1}\right)$, ADM alone $\left(1 \mathrm{mg} \cdot \mathrm{kg}^{-1} \cdot \mathrm{d}^{-1}\right)$, and $\mathrm{As}_{2} \mathrm{O}_{3}$ combined with ADM $\left(\mathrm{As}_{2} \mathrm{O}_{3} 2 \mathrm{mg} \cdot \mathrm{kg}^{-1} \cdot \mathrm{d}^{-1}+\mathrm{ADM} 1 \mathrm{mg} \cdot \mathrm{kg}^{-1} \cdot \mathrm{d}^{-1}\right)$. Each group was injected intraveously $24 \mathrm{~h}$ after transplatation once a day for 7 days continuously. The mice were killed on the 8th day after the treatment and the tumors isolated and weighed. The inhibitory rate of tumor was calculated as follows:

Inhibitory rate of tumor $(\%)=(1-$ mean tumor weight in experiments/mean tumor weight in controls $) \times 100 \%$

Statistical method Analysis of variance of two-factor factoria 1 experiment was applied to evaluate anti-cancer activity in vitro and analysis of variance of random experiment was used to evaluate anti-cancer activity in vivo. 
Evaluation of interaction of drug combination In vitro experiment: the interaction between $\mathrm{As}_{2} \mathrm{O}_{3}$ and PDD or ADM was evaluted by coefficient of drug in interaction (CDI), which was calculated as follows: $\mathrm{CDI}=\mathrm{AB} /(\mathrm{A} \times \mathrm{B})$. $\mathrm{AB}$ is the absorption ratio between a drug combination group and controls and $A$ or $B$ is that between a drug alone and controls. When CDI value was equal to 1.0 , or more than 1.0 or less than 1.0, the nature of the interaction between $\mathrm{A}$ and $\mathrm{B}$ was considered to be additive or antagonistic or synergistic ${ }^{[6]}$. In vivo experiment: the interaction between $\mathrm{As}_{2} \mathrm{O}_{3}$ and PDD or ADM was evaluated by $\mathrm{Q}$ value, which was calculated as follows: $\mathrm{Q}=\mathrm{E}(\mathrm{AB}) /[\mathrm{EA}+(1-$ $\mathrm{EA}) \times \mathrm{EB}] . \mathrm{E}(\mathrm{AB})$ is the inhibiting tumor rate and $\mathrm{EA}$ or $\mathrm{EB}$ is that of a drug alone. When $\mathrm{Q}$ value was equal to $0.85-1.15$, or less than 0.85 or more than 1.15 , additive or antagonistic or synergistic interaction was thought to occur ${ }^{[7]}$.

\section{RESULTS}

\section{The effect of $\mathrm{As}_{2} \mathrm{O}_{3}$ and/or PDD on $\mathrm{HCC}$}

The inhibition rates of $\mathrm{As}_{2} \mathrm{O}_{3}$ in vitro, in combination with PDD at various concentrations were more than that of $\mathrm{As}_{2} \mathrm{O}_{3}$ or PDD alone $\left({ }^{\mathrm{a}} P<0.01, \mathrm{~F}=58.96\right)$, in which the inhibition rates increased more evidently at low concentrations (Figure 1). CDI values of $\mathrm{As}_{2} \mathrm{O}_{3}$ and PDD in combination at low concentration were less than 1.0 (Table 1 ).

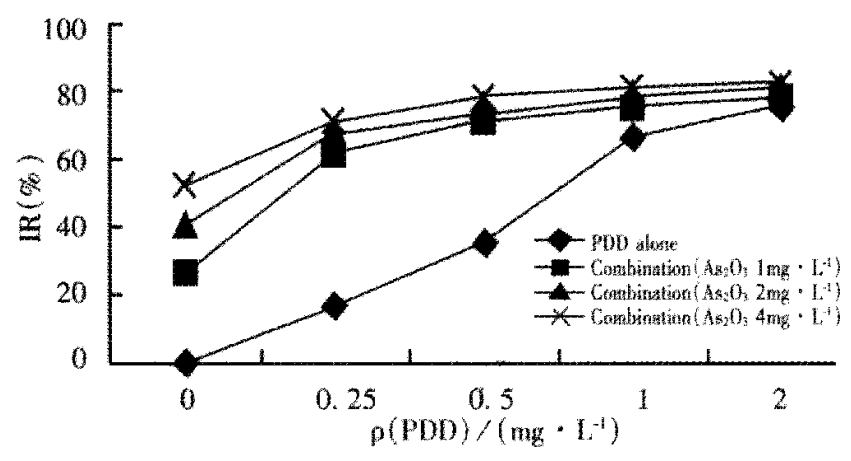

Figure 1 The effect of $\mathrm{As}_{2} \mathrm{O}_{3}$ and/or PDD on the growth of Bel-7402 cells in vitro.

Table 1 CDI value of $\mathrm{As}_{2} \mathrm{O}_{3}$ in combination with PDD against Bel7402 cells

\begin{tabular}{lcclcc}
\hline \multirow{2}{*}{ Cell line } & $\mathrm{As}_{2} \mathrm{O}_{3}(\mathrm{mg} \cdot \mathrm{L}-1)$ & \multicolumn{4}{c}{ PDD (mg.L-1) } \\
\cline { 3 - 6 } & & 0.25 & 0.5 & 1 & 2 \\
\hline Bel-7 & 1 & 0.60 & 0.60 & 1.00 & 1.22 \\
& 2 & 0.62 & 0.70 & 1.03 & 1.38 \\
& 4 & 0.60 & 0.65 & 1.13 & 1.50 \\
\hline
\end{tabular}

\section{The effect of $\mathrm{As}_{2} \mathrm{O}_{3}$ and/or $\mathrm{ADM}$ on $\mathrm{HCC}$}

In vitro the inhibition rates of $\mathrm{As}_{2} \mathrm{O}_{3}$ in combination with $\mathrm{ADM}$ in various concentrations were more than those of $\mathrm{As}_{2} \mathrm{O}_{3}$ or ADM alone ( $\left.{ }^{\mathrm{a}} \mathrm{P}<0.01, \mathrm{~F}=64.77\right)$, in which the inhibition rates increased more evidently in low concentrations (Figure 2). CDI values of $\mathrm{As}_{2} \mathrm{O}_{3}$ and $\mathrm{ADM}$ in combination in low concentrations were almost equal to 1.0 (Table 2).

\section{The effect of $\mathrm{As}_{2} \mathrm{O}_{3}$ and/or PDD on HepA implanted tumor}

The inhibiting tumor rate of $\mathrm{As}_{2} \mathrm{O}_{3}$ in combination with PDD was more than that of $\mathrm{As}_{2} \mathrm{O}_{3}$ or PDD alone and $Q$ value was more than 1.15 (Table 3).

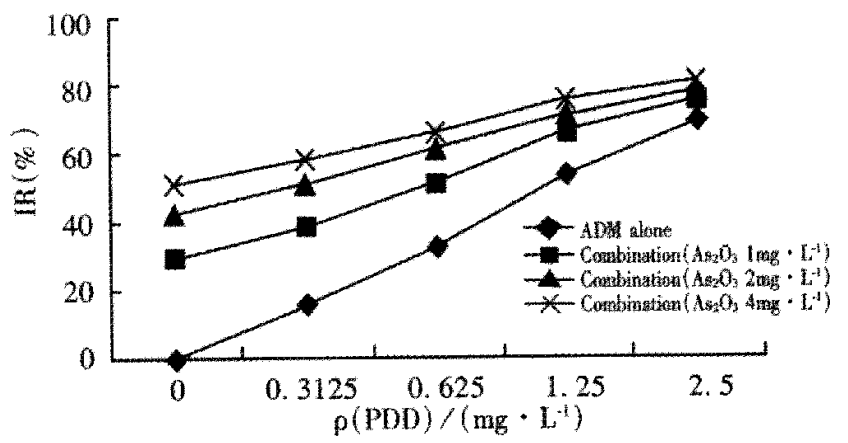

Figure 2 The effect of $\mathrm{As}_{2} \mathrm{O}_{3}$ and/or ADM on the growth of Bel-7402 cells in vitro.

Table 2 CDI value of $\mathrm{As}_{2} \mathrm{O}_{3}$ in combination with ADM against Bel7402 cells

\begin{tabular}{lcllll}
\hline \multirow{2}{*}{ Cell line } & $\mathrm{As}_{2} \mathrm{O}_{3}(\mathrm{mg} \cdot \mathrm{L}-1)$ & \multicolumn{4}{c}{$\mathrm{ADM}(\mathrm{mg} \cdot \mathrm{L}-1)$} \\
\cline { 3 - 6 } & & 0.3125 & 0.625 & 1.25 & 2.5 \\
\hline Bel-7 & 1 & 1.03 & 1.02 & 1.05 & 1.12 \\
& 2 & 1.03 & 0.98 & 1.06 & 1.31 \\
& 4 & 1.00 & 1.05 & 1.08 & 1.28 \\
\hline
\end{tabular}

Table 3 The effect of $\mathrm{As}_{2} \mathrm{O}_{3}$ and/or PDD on HepA implanted tumor in mice $(n=10)$

\begin{tabular}{|c|c|c|c|c|}
\hline Groups & 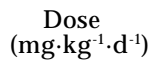 & $\underset{(\bar{x} \pm S, g)}{\text { Tumor mass }}$ & $\begin{array}{c}\text { Inhibition } \\
(\%)\end{array}$ & $\begin{array}{c}\mathrm{Q} \\
\text { value }\end{array}$ \\
\hline Control & NS & $1.53 \pm 0.35$ & & \\
\hline $\mathrm{As}_{2} \mathrm{O}_{3}$ & 2 & $1.07 \pm 0.21$ & 30.1 & \\
\hline PDD & 1 & $0.82 \pm 0.11$ & 46.2 & \\
\hline $\mathrm{As}_{2} \mathrm{O}_{3}+\mathrm{PDD}$ & $2+1$ & $0.40 \pm 0.05$ & $73.9^{a}$ & 1.18 \\
\hline
\end{tabular}

a $P<0.01, \mathrm{~F}=54.05$, vs $\mathrm{As}_{2} \mathrm{O}_{3}$ or PDD alone.

\section{The effect of $\mathrm{As}_{2} \mathrm{O}_{3}$ and/or ADM on HepA implanted tumor}

The inhibiting tumor rate of $\mathrm{As}_{2} \mathrm{O}_{3}$ in combination with ADM was higher than that of $\mathrm{As}_{2} \mathrm{O}_{3}$ or $\mathrm{ADM}$ alone and $Q$ value was less than 1.15 but more than 0.85 (Table 4 ).

Table 4 The effect of $\mathrm{As}_{2} \mathrm{O}_{3}$ and/or ADM on HepA implanted tumor in mice $(n=10)$

\begin{tabular}{lcccc}
\hline Groups & $\begin{array}{c}\text { Dose } \\
\left(\mathrm{mg}^{\mathrm{kg}} \mathrm{kg}^{-1} \cdot \mathrm{d}^{-1}\right)\end{array}$ & $\begin{array}{c}\text { Tumor mass } \\
(\overline{\mathrm{x}} \pm \mathrm{s}, \mathrm{g})\end{array}$ & $\begin{array}{c}\text { Inhibition } \\
(\%)\end{array}$ & $\begin{array}{c}\mathrm{Q} \\
\text { value }\end{array}$ \\
\hline Control & $\mathrm{NS}$ & $1.53 \pm 0.35$ & & \\
$\mathrm{As}_{2} \mathrm{O}_{3}$ & 2 & $1.07 \pm 0.21$ & & \\
$\mathrm{ADM}$ & 1 & $0.91 \pm 0.12$ & 40.5 & \\
$\mathrm{As}_{2} \mathrm{O}_{3}+\mathrm{ADM}$ & $2+1$ & $0.61 \pm 0.11$ & $60.1^{\mathrm{a}}$ & 1.03
\end{tabular}

${ }^{\mathrm{a}} \mathrm{P}<0.05, \mathrm{~F}=24.40$, vs $\mathrm{As}_{2} \mathrm{O}_{3}$ or ADM alone.

\section{DISCUSSION}

$\mathrm{As}_{2} \mathrm{O}_{3}$, the main component of traditional Chinese drug "Pishuang", has been applied to treat acute promyelocytic leukemia and yielded notable results. Complete remission rate and long-term survival rate are high and the relapse rate is low in APL patients treated with $\mathrm{As}_{2} \mathrm{O}_{3}{ }^{[8-10]}$. The main mechanism of $\mathrm{As}_{2} \mathrm{O}_{3}$ is to induce apoptosis of leukemia cells, which is different from all-trans retinoic acid (ATRA) ${ }^{[11-23]}$. Based on the achievements, the experimental studies on anti-tumor effect of $\mathrm{As}_{2} \mathrm{O}_{3}$ in such hematopathy as malignant lymphoma ${ }^{[24]}$ and myeloma $^{[25,26]}$ and solide tumors such as cancers of lung ${ }^{[27]}$, 
esophagus ${ }^{[28]}$, stomach ${ }^{[29-32]}$, colone ${ }^{[33-35]}$ pancreas $^{[36]}$, mamma $^{[37]}$, cervix ${ }^{[38]}$ and neuroblastoma ${ }^{[39]}$ are in the ascendant.

The morbidity and mortality of hepatocarcinoma is high in China, which is the first cause of death among all kinds of cancers in Jiangshu Province. Due to the hidden onset, low rates of early diagnosis and rapid progression, most patients with hepatocarcinoma cannot be operated on and have to depend on chemotherapy, but the therapeutic effect of the present agents is unsatisfactory. So it is urgent and necessary to go on seeking new drugs and the improving therapeutic METHODS. Our group has taken the lead in conducting the study of $\mathrm{As}_{2} \mathrm{O}_{3}$ against liver cancer and found that $\mathrm{As}_{2} \mathrm{O}_{3}$ had obviously selective anti-tumor effect on hepatocarcinoma both in vitro and in vivo ${ }^{[1-5]}$ : in vitro $\mathrm{As}_{2} \mathrm{O}_{3}$ inhibited the proliferation of several hepatocarcinoma cell lines but not normal human liver cells and in vivo inhibited implanted hepatocarcinoma in mice and prolonged the survival phase of mice with hepatocarcinoma but produced no obvious toxicity. The main mechanism is to induce apoptosis of hepatocarcinoma cells, which also has been proved by other reports ${ }^{[40-46]}$.

To further investigate the best therapeutic way of $\mathrm{As}_{2} \mathrm{O}_{3}$ and raise the effect on hepatocarcinoma, we studied $\mathrm{As}_{2} \mathrm{O}_{3}$ and $\mathrm{PDD}$ or ADM in combination. The experiments in vitro showed that $\mathrm{As}_{2} \mathrm{O}_{3}$ in combination with PDD or ADM can increase the effect on HCC Bel-7402 and the increase extent varies at different concentrations, which was greater at lower concentrations. The possibl e reason is that the anti-tumor activity of an individual drug is saturated at high concentrations and difficult to increase after combination or there was antagonistic action to some extent between two drugs in combination and counteracted part of anti-tumor activity of a drug. CDI values showed that in vitro the nature of interaction is markedly synergistic between $\mathrm{As}_{2} \mathrm{O}_{3}$ and PDD and addictive between $\mathrm{As}_{2} \mathrm{O}_{3}$ and $\mathrm{ADM}$ in low concentrations. On the basis of the experiments in vitro, lowdose PDD or ADM combined with $\mathrm{As}_{2} \mathrm{O}_{3}$ was applied to treat HepA tumor implanted in mice, and inhibitory rate of tumor evidently increased as compared with that of a drug alone. Q value showed that in vivo synergistic interaction between $\mathrm{As}_{2} \mathrm{O}_{3}$ and PDD and addictive between $\mathrm{As}_{2} \mathrm{O}_{3}$ and $\mathrm{ADM}$ were thought to occur, which agreed with the results in vitro. These results suggested that low-dose PDD or $\mathrm{ADM}$ and $\mathrm{As}_{2} \mathrm{O}_{3}$ in combination could increase evidently anti-hepatocarcinoma effect. PDD and ADM are the main anti-hepatocarcinoma agents, but their toxicities in kidney, liver or heart restrict their clinical application, as a result patients cannot tolerate the highdose agents whereas low dose is difficult to achieve satisfactory results. Considering selectively inhibitory effect of $\mathrm{As}_{2} \mathrm{O}_{3}$ on $\mathrm{HCC}$ in vitro and unobvious toxicity in vivo, the effect may be improved evidently without increased toxicities or keep satisfactory in poorly-tolerated patients with low dose of PDD or $\mathrm{ADM}$ when $\mathrm{As}_{2} \mathrm{O}_{3}$ and PDD or ADM in combination are applied to treat hepatocarcinoma.

\section{REERENCES}

1 Chen H, Qin SK, Chen HY, Pan QS, Ma J, Liu WH. A priliminary study on arsenic trioxide as an inducer of apoptosis in human hepatocellular carcinoma cell line. Zhongliu Fangzhi Yanjiu, 1998;25:336338

2 Chen HY, Liu WH, Qin SK. Induction of arsenic trioxide on apoptosis of hepatocarcinoma cell lines. Shijie Huaren Xiaohua Zazhi, 2000;8:532535

3 Chen H, Qin SK, Pan QS, Chen HY, Ma J. Antitumor effect of arsenic trioxide on mice experimental liver cancer. Zhonghua Ganzhangbing Zazhi, 2000;8:27-29

4 Liu L, Qin SK, Chen HY, Wang JH, Chen H, Ma J, Liu WH. An experimental study on arsenic trioxide-selectively induced human hepatocarcinoma cell lines apop tosis and its related genes. Zhonghua Ganzhangbing Zazhi, 2000;8:367-369

5 Chen H, Pan QS, Qin SK, Chen HY. An experimental study on antitumor effect of arsenic trioxide on liver cancer. Jiangsu Zhongyi, 2000;21:42-43

6 Su J, Zhen YS, Qi CQ, Chen WJ. Afungus-derived novel nucleoside transport inhibitor potentiates the activity of antitumor drugs. Yaoxue Xuebao, 1994;29:656-661

7 Yang XP, Pan QC, Xie BF, Li CJ. Antitumor effect and synergistic action of total alkaloid of common peganum. Zhongchaoyao, 1998;29: 609-611

8 Zhang P, Wang SY, Hu LH, Shi FD, Qiu FQ, Hong LJ, Han XY, Yang HF, Song YZ, Liu YP, Zhou J, Jin ZJ. Treatment of acute promyelocytic leukemia with intrav enous arsenic trioxide. Zhonghua Xueyexue Zazhi, 1996;17:58-60

9 Zhang P, Wang SY, Hu LH, Qiu FQ, Yang HF, Xiao YJ, Li XX, Han $X Y$, Zhou J, Liu P. Seven years $\bullet E$ summary report on the treatment of acute promyelocytic le ukemia with arsenic trioxide-An analysis of 242 cases. Zhonghua Xueyexue Zazhi, 2000;21:67-70

10 Soignet SL, Masiak P, Wang ZG, Jhanwar S, Calleja E, Dardashti LJ, Corso D, DeBlasio A, Gabrilove J, Scheinberg DA, Pandolfi PP, Warrell RP. Complete remission after treatment of acute promyelocytic leukemia with arsenic trioxide. N Engl J Med, 1998; 339:1341-1348

11 Chen GQ, Zhu J, Shi XG, Ni JH, Zhong HJ, Si GY, Jin XL, Tang W, Li XS, Xiong SM, Shen ZX, Sun GL, Ma J, Zhang P, Zhang TD, Gazin C, Naoe T, Chen SJ, Wang ZY, Chen Z. In vitro studies on cellular and molecular mechanisms of arsenic trioxid $\left(\mathrm{As}_{2} \mathrm{O}_{3}\right)$ in the treatment of acute promyelocytic leukemia: $\mathrm{As}_{2} \mathrm{O}_{3}$ induces $\mathrm{NB}_{4}$ cell apoptosis with downregulation of Bcl-2 expression and modulation of PML-RAR $\alpha$ / PML proteins. Blood, 1996;88:10521061

12 Chen GQ, Zhu J, Shi XG, Zhong HJ, Liu W, Jin XL, Tang W, Li XS, Ni JH, Xiong SM, Shen ZX, Ma J, Zhang P, Zhang TD, Claude G, Chen SJ, Chen Z, Wang ZY. Preliminary study on the arsenic trioxide-induced NB4 cell apoptosis and its molecular mechanisms. Zhonghua Xueyexue Zazhi, 1997;18:25-28

13 Ni JH, Chen GQ, Zhu J, Zhong HJ, Tang W, Li XS, Xiong SM, Shen ZX, Chen SJ, Wang ZY, Chen Z. Effects of arsenic trioxide on the subcellular localization of PML/PML-RAR $\alpha$ protein in leukemic cells. Zhonghua Xueyexue Zazhi, 1997;18:32-34

14 Tang W, Chen GQ, Shi GY, Jia PM, Xiong SM, Zhu J, Shi XG, Shen ZX, Chen SJ, Wang ZY, Chen Z. Double effects of arsenic trioxide $\left(\mathrm{As}_{2} \mathrm{O}_{3}\right)$ on acute promyelocytic leukemic cell line. Zhonghua Yixue Zazhi, 1997;77:509-512

15 Chen GQ, Shi XG, Tang W, Xiong SM, Zhu J, Cai X, Han ZG, Ni JH, Shi GY, Jia PM, Liu MM, He KL, Niu C, Ma J, Zhang P, Zhang TD, Paul P, Naoe T, Kiramur a K, Miller W, Waxman S, Wang ZY, de The $\mathrm{H}$, Chen SJ, Chen $\mathrm{Z}$. Use of arsenic trioxide $\left(\mathrm{As}_{2} \mathrm{O}_{3}\right)$ in the treatment of acute promyelocytic leukemia (APL): I. $\mathrm{As}_{2} \mathrm{O}_{3}$ exerts dose-dependent dual effects on APL cells. Blood, 1997;89:3345-3353

16 Shen ZX, Chen GQ, Ni JH, Li XS, Xiong SM, Qiu QY, Zhu J, Tang W, Sun GL, Yang KQ, Chen Y, Zhou L, Fang ZW, Wang YT, Ma J, Zhang $\mathrm{P}$, Zhang TD, Chen SJ, Chen Z, Wang ZY. Use of arsenic trioxide $\left(\mathrm{As}_{2} \mathrm{O}_{3}\right)$ in the treatment of acute promyelocytic leukemia (APL): II. Clinical efficacy and pharmacokinetics in relapsed patients. Blood, 1997;89:3354-3360

17 Look AT. Arsenic and apoptosis in the treatment of acute promyelocytic leukemia. J Natl Cancer Institute, 1998;90:86-87

18 Cai X, Jia PM, Shi XG, Shi GY, Zhu XH, Wang L, Chen SJ, Wang ZY, Chen $Z$, Chen GQ. In vitro study on arsenic trioxide-induced apoptosis of retinoi c acid resistant acute promyelocytic leukemia cell line (MR2). Zhonghua Xueyexue Zazhi, 1998;19:339-341

19 Li J, Sun GL, Su H, Chen HR. In vitro study on effect of two different arsenicals on NB4 cells proliferation and programmed cell death. Baixuebing, 1998;7:146-149

20 Shao W, Fanelli M, Ferrara FF, Riccioni R, Rosenauer A, Davison K, Lamph WW, Waxman S, Pelicci PG, Coco FL, Avvisati G, Testa U, Peschle C, Gambacorti-Passerini C, Nervi C, Miller WH Jr. Arsenic trioxide as an inducer of apoptosis and loss of PML/RARá protein in acute promyelocytic leukemia cells. J Natl Cancer Inst, 1998;90:124133

21 Sun YP, Chen GQ, Cai X, Huang Y, Shen SY, Jia PM, Shen YL, Yu Y, Chen SJ, Wang ZY, Chen Z. Phenylarsine oxide induces apoptosis in acute promyelocytic leukemia cell line $\mathrm{NB}_{4}$. Aizheng, 
$1999 ; 18: 1-4$

22 Huang XJ. Regulation of arsenic trioxide-inducing apoptosis. Zhonghua Xueyexue Zazhi, 1999;20:258-260

23 Wang ZX, Liao JX, Xu YG, Wang HP, Ma R, Zhou AX. Influence of antioxi dants on apoptosis induced by arsenic trioxide. Baixuebing, 2000;9:153-155

24 Zhu XH, Chen GQ, Cai X, Jia PM, Shen YL, Shi XG, Shi GY, Chen SJ, Wan $g$ ZY, Chen Z. Influence of arsenic trioxide on malignant lymphocyte. Zhonghua Xueyexue Zazhi, 1999;20:313-314

25 Rousselot P, Labaume S, Marolleau JP, Larghero J, Noguera MH, Brouet JC, Fermand JP. Arsenic trioxide and melarsoprol induce apoptosis in plasma cell lines and in plasma cells from myeloma patients. Cancer Res, 1999;59:1041-1048

26 Huang XJ, Zhou YH, Cai X, Shen YL, Jia PM, Yang J, Yuan MM, Zhang XG, Chen GQ. Effects of arsenic trioxide on multiple myeloma cells. Zhongguo Aizheng Zazhi, 2000;10:499-509

27 Deng YP, Lin C, Zhang XY, Chen JP, Xiao PG, Wu H. Studies on arsenic trioxide induced human pulmonary adenocarcinoma GLC-82 cell apoptosis and its molecular mechanisms. Aizheng, 1999;18:545549

28 Tan LJ, Shi GY, Shi XG, Tang XM. Induction of apoptosis of human esoph ageal cancer cell lines treated with arsenic trioxide. Zhongguo Aizheng Zazhi, 1999;9:85-87

29 Gu QL, Shen BH, Li NL, Zhu ZG, Yin HR, Lin YJ. A preliminary study on arsenic trioxide induced apoptosis of gastric cancer lines. Zhonghua Xiaohua Zazhi, 1998;18:69-71

30 Deng YP, Lin C, Zhang XY, Chen DQ, Xiao PG, Wu H. Arsenic trioxide induces programmed cell death of human gastric adenocarcinoma SGC7901 cells and decreases c-myc gene expression. Yaoxue Xuebao, 1999;34:333-337

31 Gu QL, Li NL, Zhu ZG, Yin HR, Lin YZ. A study on arsenic trioxide inducing in vitro apoptosis of gastric cancer cell lines. World J Gastroenterol, 2000;6:435-437

32 Tu SP, Zhong J, Tan JH, Jiang XH, Qiao MM, Wu YX, Jiang SH. Induction of apoptosis by arsenic trioxide and hydroxy camptothecin in gastric cancer cells in vitro. World J Gastroenterol, 2000;6:532-539

33 Yu BM, Cui W, Lu AG, Li DH, Zhen MH. Experimental studies on inhibito ry effect of arsenic trioxide on colon cancer. Zhongliu, 1999; 19:289-290
34 Yu BM, Cui W, Lu AG, Zheng MH, Li DH. Apoptosis of colon cancer cell induced by arsenic trioxide and its relation to cell cycle. Zhongguo Aizheng Zazhi, 2000;10:159-162

35 Zhan J, Xie DR, Yao HR, Lin XG, Liang XW, Xiang YQ. Apoptosis of colon cancer cell line SW620 induced by arsenic trioxide. Shijie Huaren Xiaohua Zazhi, 2001;9:228-229

36 Chen QK, Yuan SZ, Huang ZQ. Apoptosis of pancreatic cancer cells and blocking of its cell cycles induced by arsenic trioxide. Zhonghua Yixue Zazhi, 1998;78:578-579

37 Yang H, Yu LL, Wang XP, Ma WX, Zheng S. Apoptosis of mammary cancer cells induced by arsenic trioxide. Zhongguo Zhongliu Shengwu Zhiliao Zazhi, 1997;4:245

38 Deng YP, Lin C, Liang X, Chen JP, Fu M, Xiao PG, Wu H. Studies on induction of apoptosis of human cervicalcarcinoma cells Hela and mechanism of protec tive effect of bcl-2. Zhongguo Kexue, 1999;29:426-433

39 Wu G, Zhou YF, Ying DM, Chen TX, Wang YP, Lin Z. Preliminary studies of arsenic trioxide on the proliferation of neuroblastoma cells. Aizheng, 1999;18:263-265

40 Zhang T, Wang SS, Qi QH. The morphological and cellular dynamic changes in arsenic trioxide-treated rat liver cancer. Zhongliu, 2001;21: 101-105

41 Li JT, Qu QJ, Wei Q. Studies on arsenic trioxide induces apoptosis in hepatoma cell lines Bel-7402. Aizheng, 2000;19:1087-1091

42 Yang YL, Xu HY, Gao YY, Wu QL, Gao GQ. Influence of arsenic trioxide on human hepatoma cell line. Shijie Huaren Xiaohua Zazhi, 2000;8:1422-1423

43 Xu HY, Gao YY, Wu QL, Gao GQ, Yang YL, Chen SX, Liu TF. Proliferation inhibition and apoptosis induction by Arsenic Trioxide on human hepatoma cell line in vitro. Shijie Huaren Xiaohua Zazhi, 2000;8:1233-1237

44 Deng ZH, Cai HP, Li S, Zhang XR, Shen JW. Effects of arsenic trioxide on normal and hepatoma cell lines. Zhonghua Xiaohua Zazhi, 1999;19:227-229

45 Yang YL, Xu HY, Gao YY, Wu QL, Gao GQ. The effect of arsenic trioxide on human hepatoma cell line BEL-7402 cultured in vitro. World J Gastroenterol, 2000;6(Suppl 3):14

46 Xu HY, Yang YL, Gao YY, Wu QL, Gao GQ. Effect of arsenic trioxide on human hepatoma cell line BEL-7402 cultured in vitro. World $J$ Gastroenterol, 2000;6:681-687 